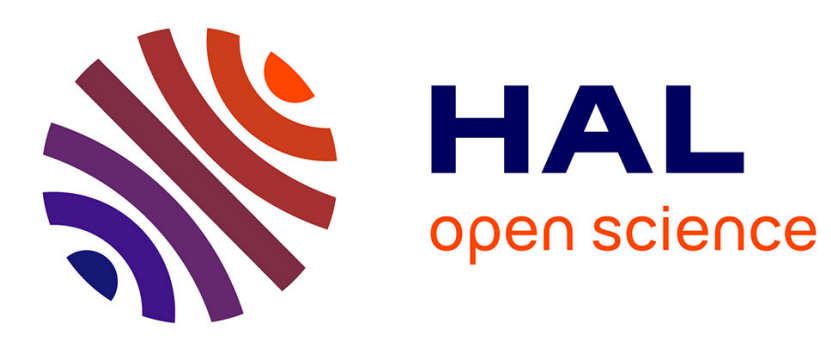

\title{
Ether complexes of molybdenum(III) and molybdenum(IV) chlorides
}

Sébastien Maria, Rinaldo Poli, K. J. Gallagher, A. S. Hock, M. J. A. Johnson

\section{To cite this version:}

Sébastien Maria, Rinaldo Poli, K. J. Gallagher, A. S. Hock, M. J. A. Johnson. Ether complexes of molybdenum(III) and molybdenum(IV) chlorides. Gregory S. Girolami; Alfred P. Sattelberger. Inorganic Syntheses, 36, Wiley, pp.15-19, 2014, Inorganic Syntheses, 9781118744871. 10.1002/9781118744994.ch03 . hal-02042499

\section{HAL Id: hal-02042499 \\ https://hal.science/hal-02042499}

Submitted on 3 Mar 2021

HAL is a multi-disciplinary open access archive for the deposit and dissemination of scientific research documents, whether they are published or not. The documents may come from teaching and research institutions in France or abroad, or from public or private research centers.
L'archive ouverte pluridisciplinaire HAL, est destinée au dépôt et à la diffusion de documents scientifiques de niveau recherche, publiés ou non, émanant des établissements d'enseignement et de recherche français ou étrangers, des laboratoires publics ou privés. 


\title{
ETHER COMPLEXES OF MOLYBDENUM(III) AND MOLYBDENUM(IV) CHLORIDE
}

\author{
Submitted by Sébastien Maria ${ }^{\mathrm{a}}$, Rinaldo Poli*a

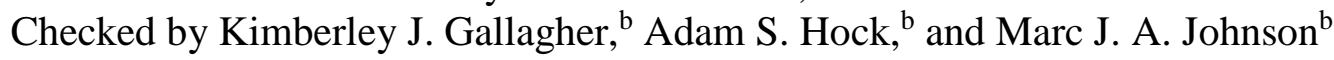 \\ ${ }^{a}$ Laboratoire de Chimie de Coordination, UPR CNRS 8241, 205 Route de Narbonne, 31077 \\ Toulouse Cedex, France \\ ${ }^{b}$ Chemical Science and Engineering Division, Argonne National Laboratory, 9700 South Cass \\ Avenue, Argonne, IL 60439, USA
}

Trichlorotris(tetrahydrofuran)molybdenum(III), $\left[\mathrm{MoCl}_{3}(\mathrm{THF})_{3}\right]$, is a widely used starting material for the synthesis of a broad range of products. Following the first reported preparation by a carbonyl route, ${ }^{1}$ the compound was then obtained by a reductive procedure in three steps starting from $\mathrm{MoCl}_{5}$, as initially reported by the Chatt group. ${ }^{2}$ This synthetic method was later improved by several minor modification, as described in three subsequent reports in Inorganic Synthesis. ${ }^{3,4,5}$ It has since remained the most widely access route to this compound. Because of the powerful Lewis acidic properties of the precursor, leading to the acid-catalysed ring opening polymerization of THF, the latter cannot be used directly as the reduction solvent. The procedure uses acetonitrile instead. $\mathrm{MoCl}_{5}$ is spontaneously reduced to $\left[\mathrm{MoCl}_{4}(\mathrm{RCN})_{2}\right]$ when dissolved in acetonitrile. In two subsequent steps, the nitrile is replaced with THF and the synthesis is then completed by a chemical reduction with tin. In spite of the various incremental ameliorations, this three-step procedure remains rather long and requires, in our hands, isolation of both $\left[\mathrm{MoCl}_{4}(\mathrm{MeCN})_{2}\right]$ and $\left[\mathrm{MoCl}_{4}(\mathrm{THF})_{2}\right]$ intermediates in order to obtain a product of sufficient quality. With individual step yields of $63-86 \%$, the overall yield from $\mathrm{MoCl}_{5}$ is $46 \%$ at best, with a time investment of $\geq 2$ days.

Contrary to THF, diethyl ether is not susceptible to polymerization and, contrary to acetonitrile, it is not susceptible to oxidation. Ethereal solutions of $\mathrm{MoCl}_{5}$ are stable and their conversion to $\left[\mathrm{MoCl}_{4}\left(\mathrm{OEt}_{2}\right)_{2}\right]$ by exotic reducing agents such as norbornene ${ }^{6}$ or allyltrimethylsilane ${ }^{7}$ has been previously reported. As it turns out, this reduction can also be conveniently carried out by metallic tin. The reduction reaction of $\mathrm{MoCl}_{5}$ by tin in ether is fast but controlled at room temperature, without an excessive exothermicity. Therefore, it does not require any special precaution. In addition, the tin chloride co-product is ethersoluble while $\left[\mathrm{MoCl}_{4}\left(\mathrm{OEt}_{2}\right)_{2}\right]$ is only sparingly soluble. Therefore, the $\mathrm{Mo}(\mathrm{IV})$ product is easily purified by ether washings with only minimal product loss. When compound $\left[\mathrm{MoCl}_{4}\left(\mathrm{OEt}_{2}\right)_{2}\right]$ is exposed to THF in the presence of metallic tin, a smooth reduction to $\left[\mathrm{MoCl}_{3}(\mathrm{THF})_{3}\right]$ occurs. This is the combination of two transformations, since the exposure to THF results in ligand exchange to $\left[\mathrm{MoCl}_{4}(\mathrm{THF})_{2}\right]$, and the latter is reduced to $\left[\mathrm{MoCl}_{3}(\mathrm{THF})_{3}\right]$ by tin as previously reported. ${ }^{5}$ This reaction gives excellent results without the need to isolate the $\left[\mathrm{MoCl}_{4}\left(\mathrm{OEt}_{2}\right)_{2}\right]$ product after its generation from $\mathrm{MoCl}_{5}$, nor the need to isolate the second $\left[\mathrm{MoCl}_{4}(\mathrm{THF})_{2}\right]$ intermediate. Thus, it suffices to use enough tin reagent to reduce $\mathrm{Mo}(\mathrm{V})$ to Mo(III) and to replace the solvent after completion of the first reduction step, in order to achieve a convenient high-yield synthesis of $\left[\mathrm{MoCl}_{3}(\mathrm{THF})_{3}\right]$ in one half day from $\mathrm{MoCl}_{5}$. This contribution describes both the synthesis and isolation of the $\left[\mathrm{MoCl}_{4}\left(\mathrm{OEt}_{2}\right)_{2}\right]$ complex, and the direct, two-step, single-flask synthesis of $\left[\mathrm{MoCl}_{3}(\mathrm{THF})_{3}\right]$ from $\mathrm{MoCl}_{5}$.

\section{TETRACHLOROBIS(DIETHYL ETHER)MOLYBDENUM(IV)}

$2 \mathrm{MoCl}_{5}+4 \mathrm{Et}_{2} \mathrm{O}+\mathrm{Sn} \rightarrow 2\left[\mathrm{MoCl}_{4}\left(\mathrm{OEt}_{2}\right)_{2}\right]+\mathrm{SnCl}_{2}$ 


\section{Procedure}

A 100-mL Schlenk tube equipped with a magnetic stir bar was connected to a vacuum/argon line through the side arm with ground-glass stopcock. After having evacuated the atmosphere and replaced it by argon three times, pentachloromolybdenum(V) $(1.20 \mathrm{~g}, 4.39 \mathrm{mmol})$ and tin powder (fine grains, $20 \mathrm{mesh} ; 1.04 \mathrm{~g}, 8.76 \mathrm{mmol}$ ) were placed in the Schlenk tube. Before use, the tin was activated by heating in an oven at $120^{\circ} \mathrm{C}$ for several hours. Freshly distilled (over sodium benzophenone ketyl under argon) ether $(30 \mathrm{~mL})$ was introduced into the Schlenk tube. The supension was then stirred at room temperature until it yielded a homogeneous suspension of an orange solid in an orange solution (about $30 \mathrm{~min}$ ). The orange solid was mechanically separated from the excess tin, taking advantage of the large difference in density between the two solids, as follows. Under gentle magnetic stirring, the metallic tin remained deposited at the bottom of the Schlenk tube and the supernatant suspension of the $\mathrm{MoCl}_{4}\left(\mathrm{Et}_{2} \mathrm{O}_{2}\right)$ product was transferred into a new Schlenk tube through a medium size (G15) cannula. The product was then collected by filtration on a glass frit, washed with $\mathrm{Et}_{2} \mathrm{O}(5 \times 5$ $\mathrm{mL}$ ), and finally dried under vacuum. The suspension may also be transferred directly from the reaction vessel onto the glass frit. However, the additional transfer to an intermediate container permits to evaluate whether any metallic tin was inadvertently transferred together with the product. It is recommended to carry out the drying procedure by maintaining the solid at $-20^{\circ} \mathrm{C}$, in order to avoid the loss of diethyl ether. The yield was $1.36 \mathrm{~g}(80 \%)$.

Anal. Calcd for $\mathrm{C}_{8} \mathrm{H}_{20} \mathrm{Cl}_{4} \mathrm{MoO}_{2}$ : C, 24.89; H, 5.22. Found: C, 25.31; H, 5.23.

\section{Properties}

Tetrachlorobis(diethyl ether)molybdenum(IV) is fine orange, air sensitive crystalline powder. It is paramagnetic, with a triplet ground state $\left(\mu_{\text {eff }}=2.33 \mu_{\mathrm{B}}\right)$. The IR spectrum is reported in the literature. ${ }^{7}$ The ${ }^{1} \mathrm{H}$ NMR spectrum in $\mathrm{C}_{6} \mathrm{D}_{6}$ shows two broad resonances for the methyl and the methylene protons of the ether ligands, at positions that are not significantly contactshifted from those of the free ether $(\delta=1.1,3.5 \mathrm{ppm})$. These resonances are not due to the coordinated ether molecules, rather to free ether molecules resulting from dissociation equilibria. The compound has a marked tendency to loose diethyl ether and samples dried without special precautions systematically gave low $\mathrm{C}, \mathrm{H}$ analyses. Heating at $80^{\circ} \mathrm{C}$ under vacuum affords a reactive form of $\mathrm{MoCl}_{4}$, which can be transformed easily and in high yields into a variety of other useful synthons, like $\left[\mathrm{MoCl}_{4}(\mathrm{THF})_{2}\right],\left[\mathrm{MoCl}_{3}(\mathrm{THF})_{3}\right],\left[\mathrm{MoCl}_{3}\left(\mathrm{PMe}_{3}\right)_{3}\right]$, or $\left[\mathrm{Mo}(\mathrm{O} t \mathrm{Bu})_{4}\right]^{8}{ }^{8}$ However, the high lability of the two diethyl ether ligands in compound $\mathrm{MoCl}_{4}\left(\mathrm{OEt}_{2}\right)_{2}$ makes the latter compound equally suitable for all those transformations. It is, in fact, more convenient to generate the $\left[\mathrm{MoCl}_{4}\left(\mathrm{OEt}_{2}\right)_{2}\right]$ material in situ, followed by its direct use in the subsequent step without the need of isolation. This strategy is detailed for the synthesis of compound $\left[\mathrm{MoCl}_{3}(\mathrm{THF})_{3}\right]$ in the next section.

\section{TRICHLOROTRIS(TETRAHYDROFURAN)MOLYBDENUM(III)}

$2 \mathrm{MoCl}_{5}+4 \mathrm{Et}_{2} \mathrm{O}+\mathrm{Sn} \rightarrow 2\left[\mathrm{MoCl}_{4}\left(\mathrm{OEt}_{2}\right)_{2}\right]+\mathrm{SnCl}_{2}$

$2\left[\mathrm{MoCl}_{4}\left(\mathrm{OEt}_{2}\right)_{2}\right]+6 \mathrm{THF}+\mathrm{Sn} \rightarrow 2\left[\mathrm{MoCl}_{3}(\mathrm{THF})_{3}\right]+4 \mathrm{Et}_{2} \mathrm{O}+\mathrm{SnCl}_{2}$

\section{Procedure}


An orange suspension of compound $\left[\mathrm{MoCl}_{4}\left(\mathrm{OEt}_{2}\right)_{2}\right]$ and excess tin in diethyl ether was prepared according to the procedure detailed in the previous section, starting from $3.18 \mathrm{~g}$ of $\mathrm{MoCl}_{5}(11.64 \mathrm{mmol})$ and $2.77 \mathrm{~g}$ of $\mathrm{Sn}(23.33 \mathrm{mmol})$ in $30 \mathrm{~mL}$ of the ether. Once the orange solid settled well in the bottom of the Schlenk tube, the supernatant liquid was decanted off by using a thin cannula, and $30 \mathrm{~mL}$ of THF (freshly distilled under argon over sodium benzophenone ketyl) was added. The resulting mixture was then stirred at room temperature until forming the product as a beige solid in a dark purple solution (ca. 4 hours). The product was separated mechanically from the excess tin taking advantage of the large difference in density between the two solids. Under gentle magnetic stirring, the metallic tin remained at the bottom of the Schlenk tube and the supernatant suspension of the $\left[\mathrm{MoCl}_{3}(\mathrm{THF})_{3}\right]$ product was transferred into a new Schlenk tube through a medium size (G15) cannula. The product was then collected by filtration on a glass frit, washed with $\mathrm{Et}_{2} \mathrm{O}(3 \times 15 \mathrm{~mL})$ and finally dried under vacuum. Like for the procedure leading to the isolation of the $\left[\mathrm{MoCl}_{4}\left(\mathrm{OEt}_{2}\right)_{2}\right]$ intermediate, the additional transfer to an intermediate container permits to evaluate whether any metallic tin was inadvertently transferred together with the product. The complex was stored under dry argon. The yield was 3.99g (82\%).

Anal. Calcd for $\mathrm{C}_{12} \mathrm{H}_{24} \mathrm{Cl}_{3} \mathrm{MoO}_{3}$ : C, 34.43; H, 5.78. Found: C, 34.04; H, 5.51.

\section{Properties}

Trichlorotris(tetrahydrofuran)molybdenum(III) has been described several times in the literature. It is a beige crystalline product that deteriorates upon exposure to the laboratory atmosphere and progressively transforms to darker dinuclear complexes upon partial loss of THF $\left(\left[\mathrm{Mo}_{2} \mathrm{Cl}_{6}(\mathrm{THF})_{4}\right]\right.$ and $\left.\left[\mathrm{Mo}_{2} \mathrm{Cl}_{6}(\mathrm{THF})_{3}\right]\right)$ when dissolved or suspended in solvents other than THF. ${ }^{9}$ It also decomposes slowly in THF, especially upon warming, with formation of 1,4 dichlorobutane and more soluble oxo derivatives whose precise nature is unknown. Therefore, it is important to avoid to leave the compound in THF for a long time in order to obtain a good yield.

\footnotetext{
${ }^{1}$ A. D. Westland, N. Muriithi, Inorg. Chem. 1972, 11, 2971-2975.

${ }^{2}$ M. W. Anker, J. Chatt, G. J. Leigh, A. G. Wedd, J. Chem. Soc., Dalton Trans. 1975, 2639-2645.

${ }^{3}$ J. R. Dilworth, R. L. Richards, Inorg. Synth. 1980, 20, 119-127.

${ }^{4}$ J. R. Dilworth, J. Zubieta, Inorg. Synth. 1986, 24, 193.

5 J. R. Dilworth, R. L. Richards, Inorg. Synth. 1990, 28, 33-37.

${ }^{6}$ L. Castellani, M. C. Gallazzi, Trans. Met. Chem. 1985, 10, 194-195.

${ }^{7}$ C. Persson, C. Andersson, Inorg. Chim. Acta 1993, 203, 235-238.

${ }^{8}$ F. Stoffelbach, D. Saurenz, R. Poli, Eur. J. Inorg. Chem. 2001, 2699-2703.

${ }^{9}$ R. Poli, H. D. Mui, J. Am. Chem. Soc. 1990, 112, 2446-2448.
} 